\title{
Ballistic Missile Defense in Poland: Did the Costs Outweigh the Benefits?
}

\author{
Colonel Steven D. Dubriske*
}

\section{Introduction}

The government of Poland has addressed a number of difficult national security issues since the nation regained its independence from Soviet control in 1989. Longstanding border disputes with neighboring countries and the perceived disparate treatment of Polish minorities in these countries are just two examples of the many external security challenges Poland faced head-on after its emergence from the Warsaw Pact. Poland's leadership has also addressed a number of internal security problems, such as the modernization of its Cold War-era military and the transfer of control of the armed forces from the Polish General Staff to civilian authorities within its Ministry of Defense.

Notwithstanding these daunting security challenges, Poland's decision to support elements of a U.S. ballistic missile defense (BMD) program on its sovereign soil has arguably posed the most complex national security dilemma for Polish leaders in this most recent chapter of its long national history. This essay will examine the decision to support the BMD program from the perspective of the Polish government, focusing in particular on the BMD program proposed and eventually implemented by the Obama Administration in 2009. After providing a historical summary of the United States' BMD program as it applies to Poland, the article will examine the domestic context within Poland, and how this context influenced the actions of government officials charged with evaluating the BMD program.

The essay will then review Poland's national interests in accepting a BMD program on its soil, and will discuss how Polish officials negotiated with the Obama Administration to gain concessions in support of these national interests. Finally, the essay will examine how the decision to support the BMD program affected Poland's long-term relationships with neighboring countries within the European Union (EU) and, most importantly, Russia. By allying with the United States and, to a certain extent, the North Atlantic Treaty Organization (NATO) on BMD, Poland put itself in the middle of a highly contentious international dispute. Given the security guarantees, military modernization, and potential economic aid that resulted from this eventual support, however, the decision by the Polish government will likely prove to be a beneficial one, as Poland continues to rapidly emerge from the shadows of the Warsaw Pact.

\footnotetext{
Colonel Dubriske is a United States Air Force officer currently serving as the Staff Judge Advocate, Headquarters Eighth Air Force (Air Forces Strategic), Barksdale Air Force Base, Louisiana. This essay was initially submitted in March 2012 as a course requirement at National War College where Colonel Dubriske was assigned as a student. The views expressed in this article are those of the author and do not reflect the official policy or position of the National Defense University, the U.S. Department of Defense, or the United States Government.
} 


\section{The Roots of the BMD Program in Poland}

Following several years of discussions with the Polish government, President George W. Bush proposed a European BMD program in early 2007. The program, similar to installations in Alaska and California that focus on ballistic missile threats from North Korea, called for the deployment of ten silo-based interceptor missiles in Poland to target ballistic missile attacks originating from Iran. ${ }^{1}$ The system, it was believed, would optimize ballistic missile defensive coverage for the United States, as well protect U.S. allies and U.S. personnel stationed in Europe. ${ }^{2}$

The Polish government, then under the leadership of President Lech Kaczynski and Prime Minister Jaroslaw Kaczynski, was eager to implement the BMD program without any U.S. concessions. The twin brothers believed the mere presence of U.S. troops on Polish soil not only markedly increased the country's defenses against foreign aggression, but also improved its relationship with what they saw as an important future ally in the United States. ${ }^{3}$ Because of these benefits, President Kaczynski and Prime Minister Kaczynski did not connect their support of the agreement to U.S. concessions on foreign aid or foreign military sales. ${ }^{4}$

In October 2007, parliamentary elections split control of the Polish government, which resulted in the replacement of Jaroslaw Kaczynski as prime minister. The new prime minister, Donald Tusk, was more cautious on the proposed BMD project, and he made it clear that his government would carefully weigh the costs and benefits of the BMD program and bargain more actively on behalf of Poland's national interests. ${ }^{5} \mathrm{Al}-$ though there were multiple discussions throughout the first half of 2008 between the United States and Poland, an agreement on the terms of the BMD program could not be reached.

Then, in early August 2008, Russian forces engaged in armed conflict with Georgia over a separatist movement in South Ossetia. Within a week of the start of this conflict, the Polish government agreed in principle to support the proposed BMD program. Under the agreement, Poland received enhanced security guarantees from the United States and a pledge to help modernize Poland's air defense system. ${ }^{6}$ The surprise decision by the Polish government to support the BMD program may have also been pushed along by U.S. discussions with Lithuania on alternative BMD basing arrangements if the agreement with Poland could not be secured in a timely manner. ${ }^{7}$

Given that over one-half of the public in Poland opposed the government's support of the BMD program, the ratification of the agreement by the Polish government was

1 Steven A. Hildreth and Carl Ek, Long-Range Ballistic Missile Defense in Europe (Washington, D.C.: U.S. Congressional Research Service, report RL34051, 23 September 2009), 1. Ibid., 6.

Kejda Gjermani, “The Missile-Defense Betrayal,” Commentary (December 2009): 24. Ibid.

Hildreth and Ek, Long-Range Ballistic Missile Defense in Europe, 10.

Ibid., 11.

Wade Boese, "U.S. Presses Poland on Anti-Missile Site," Arms Control Today 38 (July/ August 2008): 54. 
delayed as the program was subjected to public debate. ${ }^{8}$ A major subject of debate was whether the agreement, if ratified by the Polish government, would be honored by the new U.S. presidential administration after the elections of November 2008. The Poles were mainly concerned about expending political capital and alienating the Russian government only to have a new U.S. administration reject the BMD program outright. ${ }^{9}$

\section{The Obama Administration and the BMD Agreement with Poland}

Before the Polish legislature could ratify the BMD agreement, President Barack Obama was inaugurated, and honored his campaign pledge to review the European BMD program. On 17 September 2009, President Obama cancelled the previous agreement with Poland and its other partners for silo-based interceptors. ${ }^{10}$ Instead, President Obama announced the United States would adopt a new BMD program, commonly referred to as the European Phased Adaptive Approach (EPAA) program, which would deploy both sea- and land-based ballistic missile interceptors. ${ }^{11}$ Although there were initial concerns within the Polish government that Poland would not be part of the EPAA program, the Polish government agreed on 3 July 2010 to accept the deployment of land-based interceptors by $2018 .^{12}$

Given the domestic context in Poland, the securing of an agreement with the United States on the EPAA program was a significant accomplishment for the Polish government. As previously discussed above, the BMD program was never popular with the Polish public. In fact, 56 percent of the Polish population in one poll agreed with President Obama's decision to cancel the Bush-era BMD program. ${ }^{13}$ Many Poles holding this opinion felt the BMD program was purely an "American project," as Poland faced little threat from Iran. ${ }^{14}$ Comparing this minimal threat against the more realistic threat posed by a Russian government fearing NATO encirclement, the majority of the Polish population needed significant convincing from its government to support any BMD program on Polish soil. ${ }^{15}$

Previous supporters of the Bush-era BMD program also had to be swayed by the Polish government. Many supporters felt betrayed by the Obama Administration's de-

8 Gjermani, "The Missile-Defense Betrayal," 24; Hildreth and Ek, Long-Range Ballistic Missile Defense in Europe, 9.

9 Gjermani, "The Missile-Defense Betrayal," 24-25.

10 President Barack Obama, "Remarks by the President on Strengthening Missile Defense in Europe," Office of the White House, 17 September 2009; available at www.whitehouse.gov/ the_press_office/Remarks-by-the-President-on-Strengthening-Missile-Defense-in-Europe.

11 Department of State Fact Sheet, "United States European Phased Adaptive Approach (EPAA) and NATO Missile Defense," Bureau of Arms Control, Verification and Compliance, 3 May 2011.

12 Ibid.

13 Marek Madej, “Obama's Missile Defense Rethink: The Polish Reaction," The Bulletin of the Atomic Scientists (30 September 2009): 2.

14 Gjermani, "The Missile-Defense Betrayal," 24.

15 Hildreth and Ek, Long-Range Ballistic Missile Defense in Europe, 11. 
cision to cancel the initial BMD program. These supporters felt that Poland had expended significant political capital in supporting the program at home, as well as put itself in an uncomfortable position with respect to Russia, only to have the Obama Administration appease Russian objections by canceling the program. ${ }^{16}$ Additionally, many Poles felt the United States did not appreciate the contributions of Polish military forces in Iraq and Afghanistan, and that the decision to cancel the BMD program was further proof of this ingratitude. ${ }^{17}$

Because the government was subject to criticism by both supporters of the previous BMD program and opponents of any BMD program, Polish politicians had to convince the public that the revised program was in Poland's national interest. To do this, the politicians focused primarily on the security and economic benefits of the agreement with the United States. From an economic perspective, politicians noted that Poland was near the top of European countries receiving U.S. military assistance, obtaining over USD 750 million in aid since $2001 .^{18}$

Arguments for the security benefits of the BMD program were made more difficult by the fact that Poland was already a member of NATO and, therefore, possessed the Article V collective defense guarantee. Polish officials, however, argued that the bilateral agreement with the United States, entitled the "Declaration on Strategic Cooperation," provided additional protection as it had the backing of NATO's primary benefactor: the United States. ${ }^{19}$ Additionally, the temporary stationing of U.S. air defense personnel in Poland pursuant to the bilateral agreement made it unlikely that Poland's sovereignty would be violated by a neighbor out of fear of a U.S. response. This fact was recognized by a former Polish foreign minister, who publicly stated "[E]veryone agrees that countries that have U.S. soldiers on their territory do not get invaded." 20

The Polish government wisely used the threat of outside attack to drive home the security benefits of the BMD agreement with the United States. By pointing towards Russian aggression against Georgia, Polish politicians could underscore the credibility of the threat and the need for security assurances provided by the BMD agreement. ${ }^{21}$ The Polish government could also highlight not only the constant Russian rhetoric about the negative impact of the BMD program on European stability, but also Russia's threat to move mid-range nuclear missiles near the Polish border with Kalini$\operatorname{grad}^{22}$ By focusing the discussion of the benefits of the BMD program on a realistic threat, given Poland's history with Russia, Polish politicians received sufficient domestic support to pursue a BMD agreement with the United States.

16 Ibid., 2.

17 Madej, "Obama's Missile Defense Rethink," 3.

18 Karen DeYoung, "U.S., Poland Closer to Deal on Missile Defense," The Washington Post (2 February 2008): A16.

19 Hildreth and Ek, Long-Range Ballistic Missile Defense in Europe, 11.

20 Ibid., 12; Gjermani, "The Missile-Defense Betrayal," 24.

21 Gjermani, "The Missile-Defense Betrayal," 25.

22 Hildreth and Ek, Long-Range Ballistic Missile Defense in Europe, 11. 


\section{Revising the BMD Agreement}

With a minimum level of domestic support in hand, the Polish government turned toward its negotiations with the United States. While the government headed by the Kaczynski brothers only appeared to be concerned with strengthening Poland's security through the BMD program, the government of Prime Minister Tusk focused on two additional Polish national interests: military modernization and continued U.S. economic support. ${ }^{23}$ With these national interests in the forefront, Prime Minister Tusk sought to obtain additional concessions, such as the deployment of U.S. air defense batteries on Polish soil and over USD 20 billion in U.S. aid to modernize elements of the Polish military. ${ }^{24}$ While Prime Minister Tusk was unable to secure significant financial aid for modernization, the Polish government did obtain the air defense batteries, a pledge from the United States to assist Poland in the modernization of its forces, and an industrial agreement to boost Poland's defense industries through cooperative technology research and development. ${ }^{25}$

The success of the Polish negotiations with the United States can be attributed to a number of factors. Most importantly, the Polish government did not publicly overreact or criticize the United States after President Obama's decision to cancel the Bush-era BMD program. ${ }^{26}$ Some commentators in Poland lambasted the United States and labeled the decision as a "betrayal." ${ }^{27}$ Given the lack of domestic support for the BMD program, it would have been easy for the Polish government to follow suit and publicly criticize this shift in U.S. policy. Seeing the larger picture, however, Prime Minister Tusk and his government downplayed the decision and continued to voice support for a strong U.S.-Poland partnership. ${ }^{28}$ This positive approach, it could be argued, not only benefited Poland with regard to the BMD program, but also contributed to the decision by the United States to establish an aviation detachment in Poland in support of periodic deployments of U.S. aircraft to Poland on a rotational basis. ${ }^{29}$

The Tusk government also made use of the domestic unpopularity of the BMD deployment, and concerns over Russia's response, to negotiate more tangible security benefits in the form of air defense batteries. ${ }^{30}$ With regard to the Russian threat, Prime

23 Gjermani, "The Missile-Defense Betrayal," 24.

24 Ibid., 24.

25 Andrew Somerville, Ian Kearns, and Malcolm Chalmers, Poland, NATO and Non-Strategic Nuclear Weapons in Europe, Royal United Services Institute Occasional Paper (London, February 2012), 8; available at www.rusi.org/downloads/assets/Poland-NATO-and-NSNW120217.pdf.

26 It appears that the Polish government has taken a similar public position in response to the non-reassuring comments from President Obama to President Medvedev that were inadvertently recorded during a meeting in South Korea on 26 March 2012. Hildreth and Ek, Long-Range Ballistic Missile Defense in Europe, 2.

28 Ibid., 2 and 12; Madej, "Obama's Missile Defense Rethink," 2.

29 Somerville, Kearns, and Chalmers, Poland, NATO and Non-Strategic Nuclear Weapons in Europe, 8.

30 Ibid., 7. 
Minister Tusk argued that the United States should help improve Poland's air defenses to counter increasingly threatening behavior from Russia due to Poland's support of BMD. ${ }^{31}$ Russia clearly stated in public comments that Poland would be targeted if it participated in the BMD program as proposed by the United States. Thus, the Polish government believed it was reasonable for the United States to bear some of the financial cost for this added protection. While the United States and Poland attempted to downplay the appearance of a quid pro quo relationship between BMD and air defenses, a number of public statements by both U.S. and Polish governmental officials gave the appearance that air defense assistance was directly linked to the increased threat from Russia. ${ }^{32}$

\section{The European Response}

Poland's pursuit of its national interests with regard to the BMD program was not accomplished in a vacuum. As such, its negotiated agreement with the United States impacted its relationships with its European Union neighbors and Russia to varying degrees. Public opinion within Europe was overwhelmingly opposed to BMD deployment as proposed by the United States. ${ }^{33}$ Many critics argued that the BMD system was just another sign of U.S. unilateralism, which had the potential to make Europe less safe due to the alienation of Russia over the program. ${ }^{34}$ Additionally, some opponents believed Europe would not be a target of Iran if European countries rejected the U.S. plan for BMD on the continent.

Given this criticism, there were real concerns that Polish participation in the EPAA program could damage its relationship with fellow members of the European Union. ${ }^{35}$ However, Poland appears to have lost little political capital with its EU neighbors from its participation in the program. While there was some concern that Poland's actions potentially harmed overall European security because of its impact on Russia, most public criticism of the EPAA program was primarily focused on the United States and its lack of consultation with other European leaders regarding its BMD plans. ${ }^{36}$ Additionally, many EU leaders were actually supportive of the general concept of BMD and its potential to protect Europe from rogue states in the Middle East. ${ }^{37}$ Because of this inherent political support, Poland's participation in the U.S.-led program received limited criticism from EU leaders. Finally, the eventual decision by NATO to pursue

31 Boese, "U.S. Presses Poland on Anti-Missile Site," 1.

32 James Gerstenzang and Peter Spiegel, "Bush Links U.S. Aid to Poland with Missile Defense System," The Los Angeles Times (11 March 2008): A3.

33 Representative Ellen Tauscher, "European Missile Defense: A Congressional Perspective," Arms Control Today 37 (October 2007): 12.

34 Camille Grand, "Missile Defense: The View from the Other Side of the Atlantic," Arms Control Today 30 (September 2000): 12; Hildreth and Ek, Long-Range Ballistic Missile Defense in Europe, 16.

35 Hildreth and Ek, Long-Range Ballistic Missile Defense in Europe, 16.

36 Ibid., 22.

37 Ibid., 17. 
BMD capabilities for the entire alliance quickly mitigated concerns that Poland had placed its own security interests over those of other EU members.

The same cannot be said, however, for Poland's relationship with Russia. Although its negative foreign policy campaign against BMD has primarily been focused against the United States and NATO, Russia's threats of retaliatory measures have also been targeted against Poland and other European countries supporting the U.S. and NATO BMD programs. Russia believes the burgeoning BMD programs are nothing more than a precursor to more ambitious offensive programs targeted at Russia. ${ }^{38}$ Because of this perceived threat, Russian political and military leaders have both publicly stated that Poland's acceptance of BMD capabilities make it a potential target for nuclear attack by Russian forces. ${ }^{39}$

Obviously, the constant Russian rhetoric on this issue has strained diplomatic relations between Poland and Russia. While the United States has taken the lead in mitigating Russian complaints by explaining the technical limitations of the BMD program, Poland has also taken some actions to assuage Russian concerns. For example, Polish leaders made a public declaration that they would allow Russian authorities to inspect all BMD equipment on Polish soil to confirm the limited, defensive nature of the system. ${ }^{40}$ Given the strong Russian position on the threat posed by BMD, however, it is unlikely that any words or actions by the Polish government will adequately address Russian concerns. In this light, the Polish government will have to look to other areas of cooperation such as free trade and energy development to strengthen its relationship with Russia.

\section{Conclusion}

Unfortunately, in view of the fact that the BMD system will not be operational until 2018 , there is much that could change in the future with regard to the EPAA program. Increased Russian aggression and the potential for another reversal in U.S. policy could quickly change Poland's perspective on the benefits of accepting elements of the BMD program on its territory. At this point, however, it is clear that the government of Poland benefited significantly from its agreement with the United States on ballistic missile defense. The Poles improved their already solid relationship with the United States, one of the few countries Poland has historically trusted to come to its aid. Additionally, the Polish government obtained increased security guarantees against exter-

38 Ibid., 19.

39 Ibid., 21.

${ }^{40}$ Gordon Fairclough, "U.S., Poland Amend Missile-Defense Plan," Wall Street Journal (3 July 2010). 


\section{THE QUARTERLY JOURNAL}

nal threats, and also improved the capabilities of its own military forces. While the negative impact on its relations with Russia is regrettable, Poland is arguably a stronger country, partner, and ally than it was before it decided to support a ballistic missile defense program on its sovereign soil. 
SPRING 2013

\section{Bibliography}

Boese, Wade. "U.S. Presses Poland on Anti-Missile Site." Arms Control Today 38 (2008).

Fairclough, Gordon. "U.S., Poland Amend Missile-Defense Plan." Wall Street Journal (2010).

Gjermani, Kejda. "The Missile-Defense Betrayal." Commentary 24 (2009).

Grand, Camille. "Missile Defense: The View from the Other Side of the Atlantic." Arms Control Today 30 (2000): 12.

Madej, Marek. "Obama's Missile Defense Rethink: The Polish Reaction." The Bulletin of the Atomic Scientists (2009): 2.

Tauscher, Ellen. "European Missile Defense: A Congressional Perspective." Arms Control Today 37 (2007): 12. 